\section{Shifting Cultivation or Oil Palm Plantation? Integrated Assessment of Land Use Change in Dusun Tonggong, Parindu, West Kalimantan, Indonesia}

\author{
Rizky Ramadhan ${ }^{\mathrm{a}^{*}}$, Akihisa Mori ${ }^{\mathrm{a}}$, \\ Oekan S. Abdoellah ${ }^{\text {b }}$
}

${ }^{a}$ Graduate School of Global Environmental Studies, Kyoto University, Yoshida-Honmachi, Sakyo-ku, Kyoto, 6o6-8501, Japan

${ }^{b}$ Faculty of Social and Political Sciences and Senior Researcher for Environment and Sustainability Science, Universitas Padjdjaran, Jln. Raya Bandung Sumedang KM 21, Jatinagor, 45363, Indonesia

Received: November 30, 2018/ Accepted: December 2, 2019

\section{Abstract}

Since 2006, Indonesia became the largest oil palm producing country in the world. For Indonesia, oil palm is a prime commodity because it has become a source of foreign exchange. The rapid development of the oil palm industry in Indonesia resulted in a debate on the positive and negative impacts caused by the plantations, especially related to the issue of land use change. This study summarizes the quantitative aspects and the social dynamics related to land use change to oil palm plantation on mineral soil, using a comprehensive and integrated assessment. The purpose of this research is to evaluate the financial feasibility of land use change in oil palm plantation from three aspects (economy, social, and environmental aspect) and to provide a descriptive explanation of the cause of land use change from ladang to oil palm by the community. The present study suggests that the changing paradigm of the local people in the case study area to convert their ladang to oil palm plantation cannot be avoided. They prefer to plant oil palm because of three main factors: (1) economic, (2) labor force, and (3) land area.

Keywords: Oil palm; Land use Change; Integrated Assessment.

\section{Abbreviations:}

\begin{tabular}{|c|c|}
\hline PTPN & PT Perkebunan Nusantara \\
\hline ECBA & Extended Cost-Benefit Analysis \\
\hline
\end{tabular}

\begin{tabular}{lll}
\hline CPO & $:$ & Crude Palm Oil \\
$\mathrm{HCV}$ & $:$ & High Conservation Value \\
NPV & $:$ & Net Present Value
\end{tabular}

\section{Introduction}

Since 2006, Indonesia became the largest oil palm producing country in the world. For Indonesia, oil palm is a prime commodity because it has become a source of foreign exchange. Based on data from the Indonesian Ministry of Agriculture, oil palm plantations started to grow in Indonesia in 1980 with a total area of approximately 294,560 ha. The size of the land use for oil palm plantation then began to accelerate in 1998 (3,560,196 ha), and by 2015 the total area of oil palm plantation in Indonesia has reached $11,300,370$ ha $[1,2]$. The expansion of oil palm in Indonesia occurred especially in Sumatra and Kalimantan.

According to World Growth [3], there are at least three major causes of why oil palm plantations in Indonesia are growing very fast - other than the geographical conditions of Indonesia that support the development of oil palm plantations. First, CPO prices are rising sharply, due to increased consumption of edible oils and fats in China and India. Second, palm oil is a vegetable oil that has a large market share in the food and oleochemical industries. Third, oil palm has the highest and the most efficient productivity per hectare, compared to other plantations.

The rapid development of the palm oil industry in Indonesia resulted in a debate on the positive and negative impacts caused by plantations, especially related to the issue of land use change. Several NGOs persistently warn the community of the negative impact of oil palm on the environment as well as the unfairness of development from oil palm plantations that adversely affect the local community $[4,5]$. In the environmental context, some notable warnings about the environmental harm of oil palm are: activity in oil palm plantations is a source of air and water pollution, oil palm plantations cause deforestation, biofuel as a product of oil palm has no clear role in carbon storage, and impact of massive oil palm plantations on water regulation is still in debate $[6,7,8,9,10,11]$. In the social context, many social conflicts occurred due to the inability of companies to fulfil their promises to local communities or due to unfair benefit sharing [12,13]. Apart from all the negative facts aforementioned, in reality, the local community has an interest in oil palm due to the high financial return $[14,15,16]$.

\footnotetext{
1 Corresponding Author

E-mail: rizkyramadhan.015@gmail.com
} 
Some researchers who examined the impact of oil palm plantations quantitatively stated that the land use change into oil palm plantations had a positive impact on the development of the community $[17,18]$. Meanwhile, several other researchers who conducted studies on the social dynamics of communities around oil palm plantations stated that the land use change to oil palm plantations has more negative impacts on the community $[19,20]$. The debate on oil palm is considered normal since there are different perspectives to analyse the impact of oil palm. Oil palm will have positive impacts when we see this commodity as the source of community welfare that opens job opportunities for the local community. On the other hand, oil palm will have negative impacts when we see that oil palm has a potential to cause land alienation, loss of livelihoods, social conflicts, and exploitative labor relations and degraded ecosystems [21]. Despite the aforementioned facts, to the best of our knowledge, there is a lack of studies that summarize the results of quantitative impact calculations with the results of studies that describe the social dynamics of society around oil palm plantations. We believe these two aspects are important to be evaluated in one research because both are necessary to achieve sustainable oil palm plantation practices.

This study summarizes the quantitative aspects and the social dynamics related to land use change to oil palm plantations, using a comprehensive and integrated approach. The purpose of this research is to evaluate the feasibility of land use change in oil palm plantation from three aspects (economy, social, and environmental aspect) and to provide a descriptive explanation of the cause of land use change from ladang (shifting cultivation/) to oil palm by the community. To obtain a thorough analysis result, the research object for this study is limited to the Dayak Taba community in Dusun Tonggong, Parindu, West Kalimantan.

\section{Methodology}

The method used in this study is a mixed method that combines quantitative and qualitative data [22]. The data collection was conducted through field visits, semistructured interviews, and collection of secondary data which was then analyzed using the Extended Cost-Benefit Analysis (ECBA) method and described and elaborated using descriptive method. Interviews were conducted with some key informants from PTPN XIII Parindu and Dayak people in Seketam Village. In addition, a structured questionnaire was used to obtain data from local people in Seketam Village in order to understand their perception about oil palm plantation and shifting cultivation practices. Extended Cost-Benefit Analysis (ECBA) was used to analyze the financial feasibility of oil palm plantation considering the value of environmental services.

\subsection{Study Area}

This study was conducted in PTPN XIII area in Seketam Village, Parindu, West Kalimantan, Indonesia. PTPN XIII is a state-own company and one of the biggest plantation companies in West Kalimantan. Every activity in the oil palm plantation has to refer to government regulations. One regulation they have to comply with is the restriction against planting oil palm on peatland and primary forest, as per Presidential Instruction No 8/2015, Law No.5/1990, and Law No.41/1999. Thus, oil palm in PTPN XIII area is planted in mineral soil covered in shrubs. Recently, developed plantations of mineral soils remain undocumented, which comprise $88 \%$ of Kalimantan's land area [23]. Furthermore, Gunarso and colleagues [24] states that about $48 \%$ of all oil palm plantations came from the conversion of shrub or grassland areas consisting of $40 \%$ upland and $8 \%$ swamp. Due to this fact, the area of PTPN XIII is interesting to us, as we explore the activity of PTPN XIII and its impact on the economy, society, and the environment.

PTPN XIII plans to create a new oil palm plantation with an area of a thousand hectares on land that belongs to community which is a local community Dusun Tonggong area. This area is planned to be managed using a plasma-inti scheme, which consists of an estate core (inti) surrounded by a ring of smallholders outgrowers (plasma) - each provided with credit, recommended supplies of fertiliser, a first year's salary, and technical advice. This research will use this planned oil palm plantation as the research area. Dusun Tonggong has 40 households and 161 residents [25]. Dusun Tonggong is one of the areas in Parindu that has collaborated with PTPN XIII to develop oil palm plantations on their customary land since 1999.

\subsection{Community Survey}

A community survey was conducted from August 2016 to January 2017 at Seketam Village, Parindu, West Kalimantan. This village has 40 households, each of which has oil palm plantations with a plasma scheme as well as land area to build ladang using a shifting cultivation system. Each family usually has a 4 ha oil palm plantation and a 2 ha ladang. The survey aims were: to know more about land classification from Dayak people in Seketam Village, to identify the type of commodities that Dayak people obtain from ladang, to understand the necessary process to build ladang with a shifting cultivation system, and to find out recent obstacles Dayak people face in building ladang.

We conducted interviews to get information on land classification as well as on the process for and obstacles to building ladang. We also distributed questionnaires to gather information about commodities that the Dayak people get from ladang.

Key informant interviews were conducted with several people who have knowledge about oil palm issues in PTPN XIII Parindu. The interviews were divided into three categories. The first category is the expert perspective, which aims to understand the main issues of oil palm plantation in West Kalimantan. The second category is the 
corporate perspective, which aims to understand oil palm plantation practices and obstacles, as well as the main issues regarding the development of oil palm plantations. The third category is the community perspective, which aims to identify the practices of oil palm plantation from the community point of view and the main issues of oil palm development based on the community opinion.

\subsection{Measuring Environmental Services}

To be able to determine the value of environmental services, one of the necessary steps is analyzing the research area conditions, which in this research include the soil conditions and ecosystem functions of the area.

In general, the soil in Seketam Village, Parindu, West Kalimantan consists of mineral soil, with a relatively flat slope. Meanwhile, the ecosystem functions identified for the research area include five services: (1) provisioning services, (2) cultural services, (3) regulation services, (4) soil preservation, and (5) water preservation. The provisioning services, cultural services, and regulation services are already calculated by Cahyandito and Ramadhan [26] in previous research and will be used in this research to calculate extended cost-benefit analysis. The soil preservation and the water preservation services are considered based on Indonesian policy and HCV Toolkit's "environmental services" ( $\mathrm{HCV} 4)$ which are both mentioned in the working paper by Gingold and colleagues [27]. These five ecosystem services are assumed to be lost if the one thousand hectares of land owned by the village changes into oil palm plantations. Therefore, these five ecosystem services will be included in the calculation of environmental cost using the ECBA method.

To calculate water and soil conservation as environmental services from shrubland, we used a replacement cost method with the assumption that these environmental services can be replaced by using three kinds of alternatives: (1) using LCC (Leguminous Cover Crop), (2) using leaf midrib (part of the oil palm that must be pruned to keep the quality of oil palm fruit), (3) using a combination between cover crop and leaf midrib. We used secondary data from PTPN XIII to calculate the value of LCC and leaf midrib.

\subsection{Extended Cost-Benefit Analysis (ECBA)}

This research intends to calculate not only economic factors but also environmental factors through the ECBA method. A cost-benefit analysis (CBA) method may be prone to weakness in valuation due to the difficulty of reflecting the heterogeneity of different parameters [28]. To address this weakness, supplementary analyses of social, health, and environmental benefits are often introduced [29]. These additional supportive approaches are often acknowledged as an extended CBA framework [30]. ECBA is a particular manifestation of CBA with an especially careful look at social and environmental impacts - the hidden external costs normally unaccounted for in decision making [31].
When calculating using ECBA, seven scenarios were used. One scenario was the calculation of CBA excluding the environmental cost. The other six scenarios were differentiated based on the type of alternative that will be used to conserve land and water as well as based on the highest and the lowest value of cultural services. Apart from the debate about Fisher effect, interest rate was also included in the calculation to show local inflation in Sanggau area. As mentioned by Fisher, a permanent change in the rate of expected inflation will cause an equal change in the nominal interest rate in the long run [32]. In this research, we used interest rate data of the Sanggau area for the past ten years in which we noted the lowest, moderate, and highest inflation in the period.

\section{Result and Discussion}

Dayak Taba community in Dusun Tonggong is one of the local communities who decided to participate in developing oil palm through the plasma partnership scheme with PTPN XIII. However, their involvement in oil palm development has not necessarily made them leave their ladang and rubber forest. Based on the interview results with the community, nowadays they maintain their rubber forest as an alternative income source. Meanwhile, ladang play a role as a source of their subsistence needs - even though in the current existing conditions ladang area is competing with oil palm plantation which was developed based on the willingness of Dayak Taba community. The people of Dayak Taba in Dusun Tonggong classify the land into three types:

\section{Shrubland}

Shrubland is the land that is used by the community to conduct ladang using shifting cultivation method. Before oil palm, most of Dayak community in this area earned their subsistence needs from ladang.

2. Rubber forest

Rubber forest was the main source of income for Dayak before oil palm. However, lately, the price of rubber is declining. Despite that fact, nowadays, Dayak keeps the rubber land as an alternative income to oil palm.

\section{Tembawang}

Tembawang is protected land of the Dayak community, which they inherited from the previous generation. According to Sirait [18], tembawang is also known as descendant land, which is mostly used for mixed agroforestry and in some cases includes sacred forests and graveyards. The benefits obtained from these lands were shared among the descendant group and the community, with approval from the members of the community. 
In the context of land use change, within the research area, the Dayak community only allow the company to open oil palm plantations in the shrubland area. This is because tembawang and rubber forest are considered to be important assets by them.

\subsection{Ladang and Shifting Cultivation}

Ladang is land area used by Dayak people to plant corn, rice, yam, etc. for their subsistence needs. For ladang, Dayak people use a shifting cultivation system: a single, simple system of farming in which the forest or shrub is slashed and burnt to make swiddens [33]. These fields are cultivated for one or two seasons before soil fertility is exhausted or weed growth overwhelms the crops [34]. Nowadays, there is competition between ladang and oil palm because they use the same kind of area, shrubland, to plant.

The shifting cultivation practice is a system passed on from generation to generation by Dayak people [35]. This system is a sustainable system for land conditions such as those in West Kalimantan. With a rotation time of eight to fifteen years, this system allows the soil to regenerate, which enhances the fertility and the production levels of the soil. To open ladang, the Dayak people need to conduct five steps consisting of (1) nebas (cutting shrubs), (2) drying, (3) nyocol (burning the land), (4) planting, and (5) harvesting. These five steps in the process of opening ladang are shown in Figure 1. The cycle in Figure 1 keeps repeating when Dayak people need to open ladang.

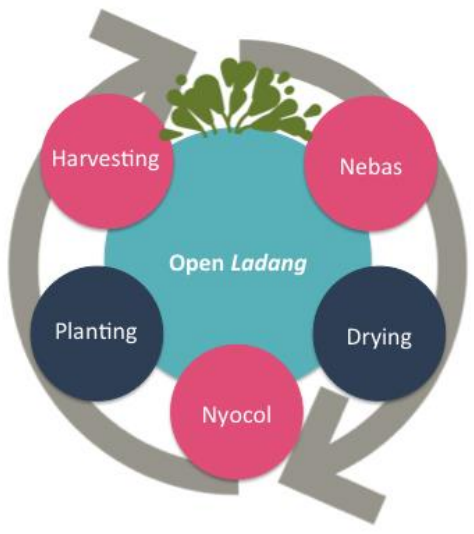

Figure 1 Process for opening Ladang

\subsection{The Obstacles to Ladang Practice}

Based on interview results, there are two main obstacles that prevent the community from opening the ladang, which are :

1. Land area: the area of ladang today has become more limited as some of the shrubs have changed to rubber and oil palm plantations. Shrinkage of land for shifting cultivation has forced many farmers to shorten their rotations. Currently, the rotation time for shifting cultivation is five years, having decreased from the ideal eight to fifteen years. This practice has affected the soil conditions as well as the land productivity of the area.

2. Labor force: Opening ladang requires 4 to 6 people. At present, most Dayak people are busy with their own oil palm plantations, which makes other Dayak people who work on their ladang feel hesitant to ask for help from other villagers. A lack of young people who stay in the village (generally, they continue their education outside the village) has also become one of the reasons which make Dayak people abandon this practice. During an interview, one of the interviewees said, "Currently, to get the labor needed to build lading is quite difficult, due to how busy each villager is."

Based on interviews with several key informants in the field, there is a tendency for the local community to change the use of their land to oil palm plantations instead of using the land for ladang with a shifting cultivation method.

\subsection{Economic Comparison}

For Dayak people, economic benefit is an important aspect to consider when they are deciding to change their land from one commodity to another. Considering this, we feel the need to compare the economic benefits of ladang with a shifting cultivation system to those of oil palm plantation, considering not only the income obtained but the environmental value from ecosystem services as well. We used three scenarios based on the variation of the local inflation rate: (1) when the local inflation is $10 \%,(2)$ when the local inflation is $8 \%$, and (3) when the local inflation rate is $4 \%$.

To undertake the evaluation using ECBA for oil palm plantations, first, we classified oil palm into four phases. The first phase is a small fruit phase, a phase in the o to $3^{\text {rd }}$ year of oil palm when the trees do not have fruit that produces oil. In general, at this phase, the company or the farmer does not have any earnings from oil palm yet. Hence, the cost in this phase is calculated as the investment cost. The second phase is the early production phase, a phase in the $4^{\text {th }}$ to $9^{\text {th }}$ year of oil palm, in which the fruit already produce oil, Though the fruits already produce oil, in the $4^{\text {th }}$ and $5^{\text {th }}$ year, there are still investment costs. The third phase is the mature production phase, spanning from the $10^{\text {th }}$ to $2 \mathrm{O}^{\text {th }}$, in this phase oil palm produce oil in optimum level. The fourth phase is when oil palm produces less oil because of aging, a phase in the $21^{\text {st }}$ to $25^{\text {th }}$ years.

In this research, we used 6 schemes to calculate ECBA (Scheme A-F, see the Appendix Table A2-A7). The schemes were developed with consideration of varied results from the tools we used to analyse the environmental services. There are range of high and low value from cultural services and three alternatives to conserve water and soil that have a role in shaping the scheme. 
A detailed calculation is shown in appendix 1 until appendix 6 . In this calculation, we also considered the value of water and soil conservation as an environmental cost that need to be replaced by the producer of oil palm who assumed to be using cover crop, leaf midrib, or combination between both of them to replace the water and soil conservation function. The result of calculation of water and soil conservation value shown in table $\mathbf{1}$.

Table 1 Water and Soil Conservation Value

\begin{tabular}{lc}
\hline Scenario & $\begin{array}{c}\text { Total } \\
\text { (\$/Ha/year) }\end{array}$ \\
\hline Cover Crop & 65.7 \\
Leaf Midrib & $9 \cdot 3$ \\
Cover Crop \& Leaf Midrib & 75 \\
\hline
\end{tabular}

Based on the calculations in all of the scenarios, taking the potential loss of environmental services into account, it is financially feasible to create oil palm in shrublands with mineral soil. Economically, the value of oil palm is higher than the value of ladang with a shifting cultivation system. As shown in Figure 2.

NPV
$10 \%$
$\mathbf{1 0} \%$
NPV Value of Palm
Oil
$\$ 736.4-\$ 1,179.8$
NPV Value of
Shifting Cultivation
$\$ 16.3-\$ 491$

Palm Oil >
Shifting
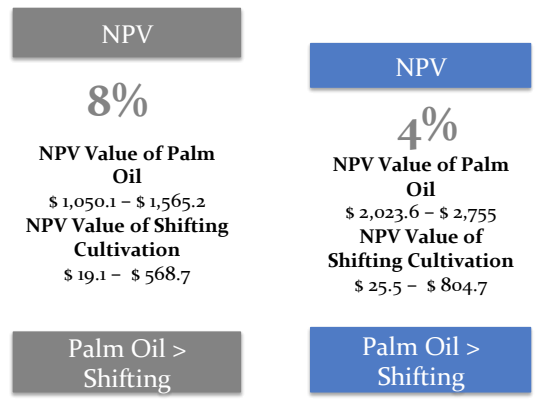

Figure 2 Economic Comparison

The Dayak community's paradigm change from subsistence needs-based (shifting cultivation/ladang) to commercially-based (oil palm plantation) can no longer be avoided. From this study, there are at least three major reasons, in no order, for this change:

\section{Economic}

Based on the calculation of ECBA, oil palm plantation or ladang with shifting cultivation are both financially feasible to build. However, if we look further at the NPV value from both practices and consider of environmental impacts, transforming shrubland into a oil palm plantation is still more profitable compared to transforming shrubland into ladang.

2. Labor Force

Based on the interview results, to open a shrubland of 2 ha until harvesting requires at least 4 to 6 people. Meanwhile, ladang is also timeconsuming for the Dayak people. This condition becomes an obstacle for some Dayak people in Seketam Village, which causes them to decide to convert their shrubland into oil palm plantations, where they do not need much labor or time.

\section{Land Area}

Based on the interview results, the area of shrubland for shifting cultivation has become smaller, caused by the increase in population and the land use changes for commercial plantations. Limited availability of land has forced many farmers to shorten their rotation on shifting cultivation, resulting in a degradation of soil conditions and the productivity of the soil. This has prompted the community to convert its land into oil palm.

Our results suggest that the three points mentioned above are the main factors which cause Dayaks to change their ladang with a shifting cultivation system to oil palm plantations. Considering these circumstances, we suggest that the future practice of oil palm should incorporate sustainable practices that consider economic, social, and environmental aspects. The understanding on the dynamics in local farmers - in this case Dusun Tonggong oil palm farmers - should also be one of the main factor to be considered in the implementation of sustainable oil palm scheme such as Roundtable on Sustainable Oil palm (RSPO), Indonesian Sustainable Palm Oil (ISPO), or Indonesian Palm Oil Pledge (IPOP). We believe such consideration will be inline with the need to achieve a sustainable development especially in oil palm industry sector.

\section{Conclusions}

The present study suggests that the changing paradigm of Dayak people leading them to convert their ladang with shifting cultivation to oil palm plantation cannot be avoided. They prefer to conduct oil palm plantation because of three main factors: (1) economic, (2) labor force, and (3) land area. In terms of the economic factor, this study proves through ECBA calculation that oil palm plantation gives more benefit than ladang with shifting cultivation, even after considering the loss of environmental services as a cost from changing to oil palm plantation. Therefore, this research suggests that to meet the needs of the Dayak people as well as to conserve the land, sustainable oil palm plantation needs to be implemented with consideration of social, economic, and environmental aspects. Such effort will be in line with Sustainable Development Goals - which Indonesia committed on - especially on point 1 on No Poverty, point 8 on Decent Work and Economic Growth, and point 15 on Life on Land. However, further, in-depth research regarding the social welfare of smallholder oil palm plantation farmers needs to be conducted to identify the real benefit of oil palm to the Dayak community. 


\section{Acknowledgements}

The author wish to thank several individuals and institutions that provided access, data, and help during this research. Our greatest thank you to PTPN XIII, Dusun Tonggong Community, Mr. Iqbal, Mr.Abi, Mr.Budhi Gunawan MA., PhD, Prof. Johan Iskandar M.Sc., Ph.D., Prof. Dr. Erry Noviar of Institute of Ecology of Univeristas Padjajaran, Mr. Parikesit MSc. Ph.D of Center for Environment and Sustainability Science of Universitas Padjajaran, and Dr. Susanti Withaningsih of Center for Environment and Sustainability Science of Universitas Padjajaran.

\section{References}

[1] Aderhold J, Davydov V Yu, Fedler F, Klausing H, Mistele D, Rotter T, Semchinova O, Stemmer J and Graul J 2001 J. Cryst. Growth 222701

[2] Kementerian Pertanian, 2016. Outlook Kelapa Sawit Komoditas Pertanian Subsektor Perkebunan. Jakarta: Pusat Data dan Sistem Informasi Pertanian.

[3] World Growth, 2011. The EconomicBenefit of Oil palm to Indonesia. World Growth Oil palm Green Development Campaign. P 27.

[4] Wakker E 2000 Funding forest destruction the involvement of Dutch banks in the financing of oil palm plantations in Indonesia. AID environment, contracts advices, telapaked. (Amsterdam: Greenpace Netherlands)

[5] Marti S 2009 Losing ground the human rights impacts of oil palm plantation expansion in Indonesia. (Friends of earth, London, UK; life mosaic, Edinburgh. UK; and Sawit Watch, Bogor)

[6] Sargeant HJ 2001 Vegetation fires in Sumatra, Indonesia. Oil palm agriculture in the wetlands of Sumatra: destruction or development? (Dinas kehutanan, Indonesia)

[7] WWF 2002 Forest landscape restoration: working examples form five ecoregion (Doveton press. Bristol)

[8] Lamade E, Bouillet JP 2005 Carbon storage and global change: the role of oil palm. Oleagineux corps gras lipide 12 (2): 154-16o

[9] Simorangkir D 2007 Fire use: Is it really the cheaper land preparation method for large-scale plantations? Mitigation Adapt Strat Glob Change 12(1):147-164

[10] Germer J, Sauerbon J 2008 Estimation of the impact of oil palm plantation establishment on greenhouse gas balance. Env Dev and Sust 10(6):697-716

[11] Danielsen F, Beukema H, Burgess ND, Parish F., Bruhl CA, Donald PF, Murdiyarso D, Phalan B, Reijnders L, Struebig M, Fitzherbert AB 2009 Biofuel plantations on forested land: double jeopardy for biodiversity and climate. Cons Biol 2(2):348-358

[12] Suyanto S. Applegate G, Permana RP, Khususiyah N, Kurniawan I 2004 The role of fire in changing land use and livelihoods in Riau-Sumatra. Ecol and Soc 9: 15. Available via http://www.ecologyandsociety.org/articles/632.html

[13] Gaiser N 2009 Oil Palm in Kalimantan: the meaning of oil palm expansion on local farmers'lives two case studies of village in Sanggau district, West Kalimantan. Bachelor of ethnology thesis. (Albert-Ludwigs University, Freiburg, Germany)

[14] Belcher B, Rujehan BM, Imang N, Achdiawan R 2004 Rattan, rubber, or oil palm: cultural and financial consideration for farmers in Kalimantan. Econ Bot 58:S77-S87
[15] Sandker M, Suwarno A. Campbell BM 2007 Will forest remain in the face of oil palm expansion? Simulating change in Malinau, Indonesia. Ecol and soc 12: 37. Available via http://www.ecologyandsociety.org/articles/2292.html

[16] Sheil D, Casson A, Meijaard E, Van Noordwjik M, Gaskell J, Sunderland-Groves J, Wertz K, Kanninnen M 2009 The impact and opportunities of oil palm in Southeasr Asia. What do we know and what do we need to know? CIFOR, (Bogor, Indonesia)

[17] Michael Euler VK 2016. Oil Palm Adoption, Household Welfare, and Nutrition Among Smallholder Farmers in Indonesia. World Development , 1 .

[18] Doni Prabowo, A., 2017. Conversion of Forests Into Oil Palm Plantation in West Kalimantan, Indonesia: Insights from Actors Power and its Dynamic. Forest Policy and Economics , 1.

[19] Sirait, M. T. (2009). Indigenous Peoples and Oil Palm Plantation Expansion in West Kalimantan, Indonesia. Cordaid memisa.

[20] Sokhannaro, H., 2011. Oil Palm Development in Cambodia. Forest Peoples Programme and Perkumpulan Sawit Watch.

[21] Colchester M, Jiwan N, Andiko MS, Sirait M, Firdaus AY, Surambo A, Pane H 2006 Promise Land. Pam oil and land acquisition in Indonesia: implication for local communities and indigenous peoples. Forest Peoples Programme/Perkumpulan Sawit Watch, Jakarta

[22] Creswell, John W 2009 Research Design Qualitative, Quantitative, and Mixed Methods Approaches. Thousand Oaks California. $\mathrm{P}_{5}$.

[23] Carlson, KM, Curran, LM, Asner, GP, Pittman AM, Trigg SN, \& Marion Adeney J 2012 Carbon emissions from forest conversion by Kalimantan oil palm plantations. Nature Climate Change, 3(3),283-287. https://doi.org/10.1038/nclimate1702

[24] Gunarso P, Hartoyo ME, Agus F \& Killeen TJ 2013 Oil Palm and Land Use Change in Indonesia, Malaysia and Papua New Guinea. Kuala Lumpur: Working Group of the Roundtable on Sustainable Oil palm (RSPO).

[25] Pemerintah Kabupaten Sanggau 2016 Laporan Perkembangan Penduduk Dusun Tonggong (Kalimantan Barat: Pemerintah Kabupaten Sanggau)

[26] Cahyandito MF and Ramadhan R 2015 Is Converting Shrub Land to Oil palm Plantation Worth it? An Ecosystem Services Analysis. Journal of Business and Retail management Research

[27] Gingold B, Rosenbarger A, Muliastra YIKD, Stolle F, Sudana IM, Manessa MDM, Murdimanto A, Tiangga SB, Madusari CC and Douard P 2012 How to Identify Degraded Land for Sustainable Oil palm Indonesia. Working Paper. (Washington DC: World Resources Institute and Sekala)

[28] Schaafsma $M$ and $R$ Brouwer 2006 Overview of existing guidelines and manuals for the economic valuation of environmental and resource costs and benefits. Working Paper, AquaMoney project, (Amsterdam, IVM)

[29] Chutubtim P 2001 Guidelines for Conducting Extended CostBenefit Analysis of Dam Projects in Thailand. (Bangkok Thailand: IDRC/CRDI Publishers)

[30] Fahrudin A 2003 Extended cost benefit analysis of present and future use of Indonesian coral reefs: An Empirical Approach to Sustainable Management of Tropical Marine Resources. Dissertation, Kiel, University, doi:oclc/76628223, (Germany)

[31] Global Green Growth Institue 2014 Extended Cost Benefit Analysis Scoping Paper. Government of Indonesia.

[32] Fisher I 1930 The Theory of Interset, Macmillan (New York).

[33] Fox J, Truong DM, Rambo AT, Tuyen NP, Cuc LT and Leisz S 20oo Shifting Cultivation: A New Old Paradigm for Managing Tropical Forests BioScience, 50(6), 521. 
https://doi.org/10.1641/ooo63568(2000)050[0521:scanop]2.0.c0;2

[34] Padoch C, Harwell E and Susanto A 1998 Swidden, Sawah, and In-Between: Agricultural Transformation in Borneo Human Ecology, 26(1), 3-20. https://doi.org/10.1023/a:1018740615905

[35] Abdoellah OS, Lahjie AB, Wangsadidjaja SS, Hadikusumah H, Iskandar J and Sukmananto B 1993 Communities and Forest Management In East Kalimantan: Pathway to Environmental Stability. (Berkley: Center for Southeast Asia Studies) 